\title{
Застосування копінг-стратегій у практиці сучасного гандболу
}

\author{
УДК 796:616.7+159.942
}

\author{
С. В. Федорчук, Д. Д. Їваскевич, О. В. Борисова, \\ і. О. Когут, В. Л. Маринич, С. В. Тукаєв, \\ Є. I. Петрушевський
}

Національний університет фізичного виховання і спорту України, Київ, Україна

\begin{abstract}
Резюме. Однією з найгостріших проблем сучасного спорту є постійно зростаючий травматизм. Хронічні перевантаження, перенапруження під час спортивних тренувань та змагань підвищують загрозу травмування та виникнення супутніх з травмами захворювань у спортсменів. Гандбол є одним із жорстких видів спорту, для якого характерна велика кількість травм і виражена тяжкість пошкоджень, основна частина яких відбувається у гравців під час проведення змагань. Безперечно, рівень стресу впливає на травматизм: навіть проблеми в міжособистісних відносинах можуть трансформуватися в стрес, підвищити ймовірність отримання травми, а, значить, призвести до припинення спортивної діяльності або передчасного завершення кар'єри. Стресостійкість є одним із основних критеріїв фізичного і психічного здоров'я спортсмена. Мета. Визначити типи копінгстратегій, які обумовлюють схильність спортсменів до травм. Методи. Для визначення пріоритетного стилю подолання стресових ситуацій або проблем у спортсменів було використано опитувальник «Виявлення індивідуальних копінг-стратегій» Е. Хайма. Результати. Найпоширенішими копінг-стратегіями серед обстежених спортсменів були: у когнітивній сфері - «збереження самовладання» та «надання сенсу»; в емоційній сфері - «оптимізм»; у поведінковій сфері - «відволікання». У цілому, серед спортсменів-гандболістів кількісно переважало використання адаптивних стратегій порівняно з неадаптивними і відносно адаптивними. Виявлено таку тенденцію: у дівчат наявність спортивних травм була пов'язана із зменшенням адаптивності емоційних та поведінкових копінг-стратегій та збільшенням частоти використання адаптивних когнітивних копінг-стратегій; у хлопців пережиті травми збільшували частоту використання адаптивних поведінкових копінг-стратегій і суттєво не позначалися на когнітивних і емоційних стратегіях подолання стресу.

Ключові слова: копінг-стратегії, спортивні травми, гандбол.
\end{abstract}

Использование копинг-стратегий в практике современного гандбола

С. В. Федорчук, Д. Д. Иваскевич, О. В. Борисова, И. О. Когут, В. Л. Маринич, С. В. Тукаев, Е. И. Петрушевский

Национальный университет физического воспитания и спорта Украины, Киев, Украина

Резюме. Одной из наиболее острых проблем современного спорта является постоянно растущий травматизм. Хронические перегрузки, перенапряжения во время спортивных тренировок и соревнований повышают угрозу травмирования и возникновения сопутствующих с травмами заболеваний у спортсменов. Гандбол является одним из жестких видов спорта, для которого характерны большое количество травм и выраженная тяжесть повреждений, основная часть которых происходит у игроков во время проведения соревнований. Безусловно, уровень стресса влияет на травматизм: даже проблемы в межличностных отношениях могут трансформироваться в стресс, повысить вероятность получения травмы, а значит, привести к прекращению спортивной деятельности или к преждевременному завершению карьеры. Стрессоустойчивость является одним из основных критериев физического и психического здоровья спортсмена. Цель. Определить типы копинг-стратегий, которые обусловливают предрасположенность спортсменов к травмам. Методы. Для определения приоритетного стиля преодоления стрессовых ситуаций или проблем у спортсменов был использован опросник «Диагностика индивидуальных копингстратегий» Э. Хайма. Результаты. Наиболее распространенными копинг-стратегиями среди 
обследованных спортсменов были: в когнитивной сфере - «сохранение самообладания» и «придание смысла»; в эмоциональной сфере - «оптимизм»; в поведенческой сфере «отвлечение». В целом среди спортсменов-гандболистов количественно преобладало использование адаптивных стратегий по сравнению с неадаптивными и относительно адаптивными. Выявлена следующая тенденция: у девушек наличие спортивных травм было связано с уменьшением адаптивности эмоциональных и поведенческих копинг-стратегий и увеличением частоты использования адаптивных когнитивных копинг-стратегий; у юношей пережитые травмы увеличивали частоту использования адаптивных поведенческих копингстратегий и существенно не сказывались на когнитивных и эмоциональных стратегиях преодоления стресса.

Ключевые слова: копинг-стратегии, спортивные травмы, гандбол.

\title{
Usage of coping strategies in the practice of modern handball \\ S. V. Fedorchuk, D. D. Ivaskevych, O. V. Borysova, i. O. Kohut, V. L. Marynych, S. v. Tukaiev, Ye. i. Petrushevskyi
}

National University of Physical Education and Sport of Ukraine, Kyiv, Ukraine

\begin{abstract}
One of the most acute problems of modern sport is the ever-increasing traumatism. Chronic overloads, strains during sports training and competitions increase the risk of injury and the occurrence of trauma related diseases in athletes. Handball is one of the toughest sports events that is characterized by a large number of injuries and the severity of damages, most of which occur during competitions. Undoubtedly, stress levels have an impact on traumatism: even problems in interpersonal relationships can be transformed into stress, increase the likelihood of injury, and thus lead to the termination of sports activities or early withdrawal. Stress resistance is one of the main criteria for an athlete's physical and mental health. Objective. To identify the types of coping strategies that determine athletes' propensity for injury. Methods. In order to determine the priority style of coping with stressful situations or problems in athletes, the questionnaire "Identification of individual coping strategies" by E. Heim was used. Results. The most common coping strategies in the surveyed athletes were: in the cognitive sphere, "maintaining self-control" and "giving meaning"; in the emotional sphere, "optimism"; in the behavioral sphere, "distraction". In general, the use of adaptive strategies was more prevalent among handball athletes compared to non-adaptive and relatively adaptive ones. The following trend was observed: in girls, the presence of sports injuries was associated with a decrease in the adaptability of emotional and behavioral coping strategies and an increased frequency of use of adaptive cognitive coping strategies; boys experienced traumas by increasing the frequency of use of adaptive behavioral coping strategies; they did not significantly affect cognitive and emotional coping strategies.

Keywords: coping strategies, sports injuries, handball.
\end{abstract}

Вступ. Однією з найгостріших проблем сучасного спорту $є$ травматизм. Загальна кількість травм у спорті дуже велика і постійно зростає. Наприклад, дослідження, проведені в Швеції, показали, що на спортивні травми доводиться до $17 \%$ всіх візитів у пункти надання невідкладної допомоги [8]. Хронічні перевантаження, перенапруження під час спортивних тренувань та змагань підвищують загрозу травмування та виникнення супутніх із травмами захворювань у спортсменів. Багато авторів відзначають прямий вплив рівня стресу на травматизм: проблеми в міжособистісних відносинах, у навчанні можуть трансорормуватися в стрес, підвищити ймовірність отримання травми, а значить, призвести до припинення спортивної діяльності або передчасного завершення кар'єри [1, 4]. Стресостійкість, толерантне ставлення до стресу $є$ одними із основних критеріїв фрізичного і психічного здоров'я спортсмена [3, 5]. Уміння спортсмена подолати стрес і соціальна підтримка дійсно знижують вплив стресу на частоту травм [6, 9]. Так, у волейболістів потужним прогностичним фактором травм визнано низький рівень уміння справлятися зі стресом [12].

У зв'язку з цим виключно важливою стороною психологічної підготовки спортсмена $є$ розвиток його здібностей до подолання стресу, формування вміння ефективно використовувати стратегії подолання стресу (копінг-стратегії) [10]. Принцип адаптивності-неадаптивності копінг-стратегій міститься в концепції методики Е. Хайма [7]. У цілому, адаптивність копінг-стратегій пов'язана з рядом позитивних результатів, у тому числі 3 суб'єктивною оцінкою свого здоров'я, соціальною підтримкою, психосоціальною адаптованістю [11]. Відомо три основні типи копінг-стратегій: 1) стратегії когнітивної адаптації; 2) стратегії поведінкової адаптації; 3) емоційно-орієнтовані стратегії [7]. 
Використання копінг-стратегій можливе не тільки у стресогенній ситуації, у разі необхідності подолання стресу, але і для запобігання дії стресора, підготовки до можливої стресової ситуації (проактивний копінг). У цілому до найбільш продуктивних стратегій подолання труднощів належать проактивний копінг, стратегії активного подолання проблем, планування діяльності, пошук соціальної підтримки і стратегії гумору. До неефективних у довгостроковій перспективі відносять стратегію уникнення, ухилення від проблем [3]. Слід зазначити, що ефективність копінг-стратегій не $є$ стабільною характеристикою. Так, фокусування уваги на проблемі може бути менш ефективною стратегією подолання стресу, ніж уникнення, якщо супроводжується емоційною інтерпретацією стресової ситуації [10]. 3 практичної точки зору, необхідність дослідження стратегій подолання будь-яких життєвих труднощів, стресу пов'язана з важливістю і необхідністю підтримання досягнутої успішності спортивної діяльності та психологічного благополуччя спортсмена [3]. Безумовно, доцільно досліджувати стрес як комплекс психологічних, психофізіологічних, фрізіологічних реакцій спортсменів на стресову ситуацію, у тому числі з метою прогнозування ризику травматизму спортсменів.

Отже, можна зробити цілком логічне припущення, що наявність або відсутність травм у спортсменів може позначатися на адаптивностінеадаптивності копінг-стратегій.

Мета дослідження - визначити типи копінгстратегій, які обумовлюють схильність спортсменів до травм.

Зв'язок дослідження 3 науковими програмами, планами, темами. Роботу виконано відповідно до держбюджетної науково-дослідної теми «Технологія оцінки ризику травматизму спортсменів за електронейроміографрічними і психофрізіологічними показниками» (номер держреєстрації 0119U000307) Міністерства освіти і науки України.

Методи дослідження. У проведеному дослідженні взяли участь 35 спортсменів-гандболістів віком 15-16 років обох статей: 22 дівчини і 13 хлопців. Для вивчення стратегій подолання стресу (копінг-стратегій) і визначення пріоритетного стилю подолання стресових ситуацій або проблем у спортсменів було використано опитувальник "Виявлення індивідуальних копінг-стратегій» Е. Хайма [7], який дозволяв досліджувати 26 ситуаційно-специфічних варіантів копінгу, розподілених відповідно до трьох основних сфер психічної діяльності на когнітивний, емоційний і поведінковий копінг-механізми. Види копінг-по- ведінки Е. Хайм розподілив на три основні групи за ступенем їх адаптивних можливостей: адаптивні, відносно адаптивні і неадаптивні.

До адаптиВних ВаріантіВ копінг-поведінки серед когнітивних копінг-стратегій належать: «проблемний аналіз», «встановлення власної цінності», «збереження самовладання». Серед емоційних копінг-стратегій цієї групи виділяють «протест», «оптимізм». До поведінкових копінг-стратегій належать: «співпраця», «звернення», «альтруїзм».

До неадаптиВних Варіантів копінг-поведінки серед когнітивних копінг-стратегій належать: «смиренність», «розгубленість», «дисимуляція», «ігнорування». Серед емоційних копінг-стратегій цієї групи виділяють: «пригнічення емоцій», «покірність», «самозвинувачення», «агресивність». До поведінкових копінг-стратегій належать: «активне уникнення», «відступ».

Серед Відносно адаптиВних Варіантів копінг-поведінки, конструктивність яких залежить від значущості і вираженості ситуації подолання також виділяють три групи. До когнітивних копінг-стратегій входять: «відносність», «надання сенсу», «релігійність». Серед емоційних копінгстратегій виділяють: «емоційну розрядку», «пасивну кооперацію». До поведінкових копінг-стратегій належать: «компенсація», «відволікання», «конструктивна активність».

Під час проведення комплексних психологічних і біологічних досліджень за участю спортсменів відповідно до принципів біоетики дотримувалися розробленої в лабораторії теорії і методики спортивної підготовки і резервних можливостей спортсменів НДІ НУФВСУ «Програми комплексного біологічного дослідження особливостей функціональних можливостей спортсменів», а також законодавства України про охорону здоров'я та Гельсінської декларації 2000 р., директиви Європейського товариства $86 / 609$ щодо участі людей у медико-біологічних дослідженнях [2].

Результати та їх обговорення. Одним із завдань нашого дослідження було виявлення типів копінг-поведінки спортсменів у зв'язку 3 наявністю спортивних травм під час тренувальної та змагальної діяльності. Було проведено дослідження копінг-поведінки гандболістів-юніорів для подальшого порівняння отриманих результатів щодо наявності або відсутності травм у групах 3 адаптивними, відносно адаптивними і неадаптивними стратегіями подолання стресу.

Обробка даних, отриманих у процесі дослідження за методикою Е. Хайма, показала таке. Використання когнітивних адаптивних стратегій було характерно для 54,29 \% спортсменів 
ТАБЛИЦЯ 1 - Копінг-стратегії спортсменів-гандболістів за тестом Е. Хейма (n = 35)

\begin{tabular}{|l|c|c|}
\hline \multicolumn{1}{|c|}{ Копінг-стратегії } & $\begin{array}{c}\text { Кількість спортсменів, } \mathbf{n} \\
\text { (n хлопців; } \mathbf{n} \text { дівчат) }\end{array}$ & $\begin{array}{c}\text { Кількість спортсменів, \% } \\
\text { (\% хлопців; \% дівчата }\end{array}$ \\
\hline & Когнітивні копінг-стратегії & $54,29(46,15 ; 59,09)$ \\
Адаптивні стратегії & $19(6 ; 13)$ & $11,43(23,08 ; 4,55)$ \\
Неадаптивні стратегії & $4(3 ; 1)$ & $34,29(30,77 ; 36,36)$ \\
Відносно адаптивні стратегії & $12(4 ; 8)$ & $68,57(76,92 ; 63,64)$ \\
Адаптивні стратегії & Емоційні копінг-стратегії \\
Неадаптивні стратегії & $24(10 ; 14)$ & $25,71(23,08 ; 27,27)$ \\
Відносно адаптивні стратегії & $9(3 ; 6)$ & $5,71(0,00 ; 9,09)$ \\
& $2(0 ; 2)$ & $37,14(38,46 ; 36,36)$ \\
Адаптивні стратегії & Поведінкові копінг-стратегії \\
Неадаптивні стратегії & $13(5 ; 8)$ & $14,29(15,38 ; 13,64)$ \\
Відносно адаптивні стратегії & $5(2 ; 3)$ & $48,57(46,15 ; 50,00)$ \\
\hline
\end{tabular}

ТАБЛИЦЯ 2 - Класифікація копінг-стратегії (Хайм, 1995)

\begin{tabular}{|c|c|c|c|}
\hline Види стратегії & У когнітивній сфері & В емоційній сфері & У поведінковій сфері \\
\hline $\begin{array}{l}\text { Адаптивні } \\
\text { стратегії }\end{array}$ & $\begin{array}{l}\text { «Проблемний аналіз», «встановлення } \\
\text { власної цінності», «збереження само- } \\
\text { владання» }\end{array}$ & «Протест», «оптимізм» & $\begin{array}{l}\text { «Співпраця», «звернення», } \\
\text { «альтруїзм» }\end{array}$ \\
\hline $\begin{array}{l}\text { Неадаптивні } \\
\text { стратегії }\end{array}$ & $\begin{array}{l}\text { «Смиренність», «розгубленість», «дис- } \\
\text { симуляція», «ігнорування» }\end{array}$ & $\begin{array}{l}\text { «Пригнічення емоцій», «покірність», } \\
\text { «самозвинувачення», «агресивність» }\end{array}$ & $\begin{array}{l}\text { «Активне уникнення», «від- } \\
\text { ступ» }\end{array}$ \\
\hline $\begin{array}{l}\text { Відносно адап- } \\
\text { тивні стратегії }\end{array}$ & $\begin{array}{l}\text { «Відносність», «надання сенсу», } \\
\text { «релігійність» }\end{array}$ & $\begin{array}{l}\text { «Емоційна розрядка», «пасивна } \\
\text { кооперація» }\end{array}$ & $\begin{array}{l}\text { «Компенсація», «відволікання», } \\
\text { «Конструктивна активність» }\end{array}$ \\
\hline
\end{tabular}

(46,15\% і 59,09 \% відповідно у хлопців і дівчат). Когнітивні неадаптивні стратегії виявлено у $11,43 \%$ спортсменів $(23,08 \%$ і 4,55 \% відповідно у хлопців і у дівчат). Використання когнітивних відносно адаптивних стратегій зафіксовано у $34,29 \%$ спортсменів $(30,77 \%$ і $36,36 \%$ відповідно у хлопців і у дівчат).

Емоційні адаптивні копінг-стратегії були характерні для 68,57 \% спортсменів (76,92 \% i $63,64 \%$ відповідно у хлопців і у дівчат). Використання емоційних неадаптивних стратегій виявилося властивим для 25,71\% спортсменів (23,08 \% і 27,27 \% відповідно у хлопців і у дівчат). Використання емоційних відносно адаптивних стратегій було характерно для 5,71 \% спортсменів $(0,00 \%$ і 9,09 \% відповідно у хлопців і у дівчат).

Використання поведінкових адаптивних копінг-стратегій виявлено у 37,14 \% спортсменів (38,46 \% і 36,36 \% відповідно у хлопців і у дівчат). Поведінкові неадаптивні стратегії діагностовано у 14,29 \% спортсменів (15,38 \% і 13,64\% відповідно у хлопців і дівчат). Використання відносно адаптивних поведінкових стратегій було характерним для 48,57 \% спортсменів $(46,15 \%$ і 50,00 \% відповідно у хлопців і у дівчат) (табл. 1).
Найпоширенішими копінг-стратегіями серед обстежених спортсменів були: у когнітивній сорері - «збереження самовладання» та «надання сенсу»; в емоційній сорері - «оптимізм»; у поведінковій сорері - «відволікання». У цілому серед спортсменів кількісно переважало використання адаптивних стратегій порівняно з неадаптивними і відносно адаптивними (див. табл. 1). Серед адаптивних і неадаптивних копінг-стратегій найбільш поширеними у спортсменів були емоційні стратегії. Серед відносно адаптивних копінг-стратегій переважали поведінкові відносно адаптивні стратегії.

Серед поведінкових копінг-стратегій до адаптивних варіантів копінг-поведінки належать (табл. 2): «співпраця», «звернення», «альтруїзм - під якими розуміється така поведінка особистості, при якій вона вступає в співпрацю зі значущими (більш досвідченими) людьми, шукає підтримки в найближчому соціальному оточенні або сама пропонує її близьким у подоланні труднощів. До неадаптивних варіантів копінг-поведінки серед поведінкових стратегій відносять (див. табл. 2): «активне уникнення», «відступ» поведінку, яка передбачає уникнення думок про неприємності, пасивність, усамітнення, спокій, 
ТАБЛИЦЯ 3 - Копінг-стратегії спортсменів-гандболістів у зв'язку з наявністю або відсутністю травм $(\mathbf{n}=35)$

\begin{tabular}{|c|c|c|c|c|}
\hline \multirow{2}{*}{ Копінг-стратегії } & \multicolumn{2}{|c|}{ Спортсмени з травмами $(\mathrm{n}=\mathbf{2 3})$} & \multicolumn{2}{|c|}{ Спортсмени без травм $(n=12)$} \\
\hline & $\begin{array}{l}\text { Кількість спортсменів, } \\
\text { n, (n хлопців; n дівчат) }\end{array}$ & $\begin{array}{c}\text { Кількість } \\
\text { спортсменів, \% }\end{array}$ & $\begin{array}{l}\text { Кількість спортсменів, n, } \\
\text { (n хлопців; n дівчат) }\end{array}$ & $\begin{array}{c}\text { Кількість } \\
\text { спортсменів, \% }\end{array}$ \\
\hline \multicolumn{5}{|c|}{ Когнітивні копінг-стратегії } \\
\hline Адаптивні стратегії & $13(3 ; 10)$ & 56,52 & $6(3 ; 3)$ & 50,00 \\
\hline Неадаптивні стратегії & $2(1 ; 1)$ & 8,7 & $2(2 ; 0)$ & 16,67 \\
\hline Відносно адаптивні стратегії & $8(2 ; 6)$ & 34,78 & $4(2 ; 2)$ & 33,33 \\
\hline \multicolumn{5}{|c|}{ Емоційні копінг-стратегії } \\
\hline Адаптивні стратегії & $15(5 ; 10)$ & 65,22 & $9(5 ; 4)$ & 75,00 \\
\hline Неадаптивні стратегії & $7(1 ; 6)$ & 30,43 & $2(2 ; 0)$ & 16,67 \\
\hline Відносно адаптивні стратегії & $1(0 ; 1)$ & 4,35 & $1(0 ; 1)$ & 8,33 \\
\hline \multicolumn{5}{|c|}{ Поведінкові копінг-стратегії } \\
\hline Адаптивні стратегії & $10(4 ; 6)$ & 43,48 & $3(1 ; 2)$ & 25,00 \\
\hline Неадаптивні стратегії & $3(1 ; 2)$ & 13,04 & $2(1 ; 1)$ & 16,67 \\
\hline Відносно адаптивні стратегії & $10(1 ; 9)$ & 43,48 & $7(5 ; 2)$ & 58,33 \\
\hline
\end{tabular}

ізоляцію, прагнення піти від активних інтерперсональних контактів, відмову від вирішення проблем. Серед відносно адаптивних варіантів копінг-поведінки, конструктивність яких залежить від значущості і вираженості ситуації подолання, виділяють (див. табл. 2): «компенсацію», «відволікання», «конструктивну активність» (поведінкові копінг-стратегії), тобто поведінку, що характеризується прагненням до тимчасового відходу від вирішення проблем [7].

Як це пов'язано зі спортивними травмами? Загалом, наявність травм у обстежених спортсменів-гандболістів позначилася у помітному зменшенні частоти використання адаптивних емоційних копінг-стратегій і, відповідно, у збільшенні частоти використання неадаптивних емоційних копінг-стратегій.

Прямо протилежна тенденція спостерігалася щодо когнітивних і поведінкових копінг-стратегій: наявність травм позначилася у помітному зменшенні частоти використання неадаптивних когнітивних і відносно адаптивних поведінкових копінг-стратегій і, відповідно, у збільшенні частоти використання адаптивних когнітивних і поведінкових копінг-стратегій обстеженими спортсменами (табл. 3). Слід зазначити, що на когнітивних стратегіях подолання стресу наявність травм позначилася менш суттєво, тоді як на поведінкових копінг-стратегіях - найбільш помітно.

Якщо проаналізувати копінг-стратегії окремо в групах хлопців і дівчат, можна виявити деякі особливості переважання певних стратегій подолання стресу залежно від наявності або відсутності спортивних травм у спортсменів. У дівчат наявність травм ( $=17$ ) зменшувала адаптивність емоційних і поведінкових копінг-стратегій, але збільшувала адаптивність когнітивних стратегій. У хлопців $(n=6)$, навпаки, наявність спортивних травм збільшувала частоту використання адаптивних поведінкових копінг-стратегій і суттєво не позначилася на когнітивних і емоційних стратегіях подолання стресу. Але, зважаючи на малу кількість спортсменів серед нетравмованих хлопців і дівчат (відповідно, $\mathrm{n}=7 \mathrm{i} n=5$ ) і серед травмованих хлопців $(n=6)$, остаточні висновки робити все таки завчасно.

\section{Висновки}

1. Найпоширенішими копінг-стратегіями серед обстежених спортсменів були: в когнітивної сорері - «збереження самовладання» та «надання сенсу»; в емоційній сорері - «оптимізм»; у поведінковій ссрері - «відволікання». У цілому серед спортсменів кількісно переважало використання адаптивних стратегій порівняно з неадаптивними і відносно адаптивними.

2. Серед адаптивних і неадаптивних копінгстратегій найбільш поширеними у спортсменів були емоційні стратегії. Серед відносно адаптивних копінг-стратегій переважали поведінкові відносно адаптивні стратегії.

3. Виявлено таку тенденцію: у дівчат наявність спортивних травм була пов'язана зі зменшенням адаптивності емоційних та поведінкових копінгстратегій та збільшенні частоти використання адаптивних когнітивних копінг-стратегій; у хлопців пережиті травми збільшували частоту використання адаптивних поведінкових копінг-стратегій і суттєво не позначалися на когнітивних $\mathrm{i}$ емоційних стратегіях подолання стресу. 
Перспективи подальших досліджень. Цікавим $\epsilon$ подальше дослідження з проведенням порівняльного аналізу психологічних і психофізіологічних по-

Література

1. Бочавер К. А. Совладающее поведение в профессиональном спорте: феноменология и диагностика [Электронный ресурс] / К. А. Бочавер, Л. М. Довжик // Клинич. и спец. психология». - 2016. - № 5 (1). C. 1-18. Doi: 10.17759/psyclin.2016050101

2. Шинкарук О. А. Медико-біологічне забезпечення підготовки спортсменів збірних команд України з олімпійських видів спорту / О. А. Шинкарук, О. М. Лисенко, Л. М. Гуніна та ін. - К.: Олімп. л-ра; 2009. - 144 c.

3. Рассказова Е. И. Копинг-стратегии в структуре деятельности и саморегуляции: психометрические характеристики и возможности применения методики СОРЕ / Е. И. Рассказова, Т. О. Гордеева, Е. Н. Осин // Психология. - 2013. - № 1. - С. 82-118.

4. Шинкарук О. Стрес та його вплив на змагальну та тренувальну діяльність спортсменів // Фізична культура, спорт та здоров'я нації: зб. наук. пр. / О. Шинкарук, О. Лисенко, С. Федорчук. - 2017. T 3, № 22. - C. 469-476. http://93.183.203.244:8080/xmlui/ handle/123456789/646

5. Fedorchuk S. The psychophysiological state of highly qualified athletes performing in diving with different levels of anxiety / S. Fedorchuk, S. Tukaiev, O. Lysenko, O. Shynkaruk // European Psychiatry, Elsevier. 2018. - N 48. - P. 681.

6. Hardy C. J. The role of social support in the life stress/injury relationship / C. J. Hardy, J. M. Richman, L. B. Rosenfeld // Sport Psychol. - 1991. Vol. 5, N 128. - C. 39.

7. Heim E. Coping based intervention strategies / E. Heim // Patient education and counseling. - 1995. - Vol. 26, N 1-3. - P. 145-151.

8. Renstrom PAFH // Sports injuries. - 2002. - P. 11-12.

9. Sarason I. G. Social support, personality, and performance / I. G. Sarason, J. H. Sarason, G. R. Pierce // J. Appl. Sport Psychol. - 1990. N 2 (117). - P. 27.

10. Suls $J$. The relative efficacy of avoidant and nonavoidant coping strategies: A meta-analysis / J. Suls, B. Fletcher // Health Psychology. 1985. - N 4(3). - P. 249-288.

11. Vaillant G. E. Adaptive mental mechanisms. Their role in a positive psychology / G. E. // Vaillant American Psychologist. - 2000. - N 55 (1). - P. 89-98.

12. Williams J. M. Relationship of life stress to injury in intercollegiate volleyball / J. M. Williams, P. Tonymon, W. A. Wadsworth // J. Hum. Stress. 1986. - N 12. - P. 38-43. казників у спортсменів, що спеціалізуються в різних видах спорту та в процесі профресійної діяльності зазнають впливу навантажень різних типів.

\section{References}

1. Бочавер КА, Довжик ЛМ. Совладающее поведение в профессиональном спорте: феноменология и диагностика. Электронный журнал «Клиническая и специальная психология». 2016; 5 (1);1-18. doi: 10.17759/psyclin.2016050101

2. Шинкарук ОА, Лисенко ОМ, Гуніна ЛМ, Карленко ВП, Земцова II, Олішевський СВ, та ін. Медико-біологічне забезпечення підготовки спортсменів збірних команд України з олімпійських видів спорту. [Medico-biological support for preparation of athletes of Ukrainian national teams in the Olympic sports events]. К.: Олімпійська літ; 2009. $144 \mathrm{c}$.

3. Рассказова ЕИ, Гордеева ТО, Осин ЕН. Копинг-стратегии в структуре деятельности и саморегуляции: психометрические характеристики и возможности применения методики COPE [Coping strategies in the structure of activity and self-regulation: psychometric characteristics and opportunities of using COPE methods]. Психология. Журнал ВШЭ. 2013;1:82-118.

4. Шинкарук О, Лисенко О, Федорчук С. Стрес та його вплив на змагальну та тренувальну діяльність спортсменів. Фізична культура, спорт та здоров'я нації: збірник наукових праць [Stress and its impact on training and competitive activity of athletes]. 2017;3(22):469-76. http://93.183.203.244:8080/xmlui/handle/123456789/646

5. Fedorchuk S, Tukaiev S, Lysenko O, Shynkaruk O. The psychophysiological state of highly qualified athletes performing in diving with different levels of anxiety. Eur. Psychiatry, Elsevier. 2018; 48: 681.

6. Hardy CJ, Richman JM, Rosenfeld LB. The role of social support in the life stress/injury relationship. Sport Psychol. 1991.5,128:39.

7. Heim E. Coping based intervention strategies. Patient education and counseling. 1995;26(1-3):145-51.

8. Renstrom PAFH. Sports injuries. 2002.11-12.

9. Sarason IG, Sarason JH, Pierce GR. Social support, personality, and performance. J. Appl. Sport Psychol. 1990;2(117):27.

10. Suls J, Fletcher B. The relative efficacy of avoidant and nonavoidant coping strategies: A meta-analysis. Health Psychology. 1985;4(3):24988.

11. Vaillant GE. Adaptive mental mechanisms. Their role in a positive psychology. American Psychologist. 2000;55(1):89-98.

12. Williams JM, Tonymon $P$, Wadsworth WA. Relationship of life stress to injury in intercollegiate volleyball. J. Hum. Stress. 1986;12:38-43. 